\title{
Ortaokul Öğrencilerinin Takım Çalışması ve Karar Verme Ĕgilimlerinin İncelenmesi
}

\section{Investigation of Middle School Students' Teamwork and Decision Making Inclinations İsa DEVECi'}

- Geliş Tarihi: $10.02 .2019 \bullet$ Kabul Tarihi: 11.03.2019 • Yayın Tarihi: 21.06.2019

\begin{abstract}
$\ddot{O} z$
$\mathrm{Bu}$ araştırmanın amacı; öğrencilerin takım çalışması ve karar verme eğilimlerini çeşitli değişkenler açısından incelemek ve bunun yanında takım çalışması ile karar verme eğilimleri arasındaki ilişkiyi belirlemektir. Araştırmaya kolay ulaşılabilir örnekleme yöntemi ile üç ortaokuldan seçilen 522 öğrenci katılmıştır. Veriler demografik bilgilerin yer aldığı demografik bilgi formu, "Grup Çalışması Ölçeği” ve "Karar Verme Ölçeği” kullanılarak elde edilmiştir. Verilerin analizinde üç yol MANCOVA, ANCOVA, basit doğrusal regresyon analizi ve basit korelasyon analizlerinden yararlanılmıştır. Sonuç olarak karar verme eğilimleri incelendiğinde; cinsiyet açısından kız öğrencilerin erkek öğrencilerden, sınıf düzeyi açısından yedinci sınıf öğrencilerinin beşinci sınıf öğrencilerinden, akademik başarı açısından not ortalaması yüksek olan öğrencilerin not ortalaması düşük olan öğrencilerden istatistiksel olarak anlamlı düzeyde karar verme eğilimlerinin daha yüksek olduğu belirlenmiştir. Takım çalışması eğilimleri incelediğinde; cinsiyet açısından anlamlı farklılığın olmadığı, sınıf düzeyi açısından ise beşinci ve altıncı sınıf öğrencilerinin sekizinci sınıf öğrencilerinden, akademik başarı açısından not ortalaması yüksek olan öğrencilerin not ortalaması düşük olan öğrencilerden istatistiksel olarak anlamlı düzeyde takım çalışması eğilimlerinin daha yüksek olduğu belirlenmiştir. Diğer taraftan öğrencilerin takım çalışması ve karar verme eğilimleri arasında pozitif yönlü düşük düzeyde bir ilişki olduğu, bunun yanında öğrencilerin takım çalışması eğilimlerinin, karar verme eğilimlerini \% 4 oranında anlamlı derecede yordadığı belirlenmiştir.
\end{abstract}

Anahtar sözcükler: Takım çalışması, karar verme, cinsiyet, sınıf düzeyi, akademik başarı

Atıf:

Deveci, İ. (2019). Ortaokul öğrencilerinin takım çalışması ve karar verme eğilimlerinin incelenmesi. Pamukkale Üniversitesi Ĕ̆itim Fakültesi Dergisi, 47, 311-330. doi: 10.9779/pauefd.525059

\footnotetext{
* Doç. Dr., Kahramanmaraş Sütçü İmam Üniversitesi, Eğitim Fakültesi, Fen Bilgisi Eğitimi A.B.D., ORCİD: 00000003-0191-1212,deveciisa@gmail.com
} 


\begin{abstract}
The aim of this research is to investigate the students' teamwork and decision making inclinations in terms of gender, grade level and academic success, as well as to determine the relationship between teamwork and decision making inclinations. The sample of this research is composed of 522 5th-8th grade middle school students. The "Student Attitudes Towards Group Environments Scale" and the "Decision Making Scale" were used as data collection tools. Three-way MANCOVA, ANCOVA, simple linear regression and simple correlation analysis were used to analyze the data. Finally, according to decision-making inclinations, it was determined that female students were more positive than male, seventh grade students were more positive than fifth grade students, and students with higher GPAs were more positive than those with lower GPAs. In terms of students' teamwork inclinations, it was determined that there is no significant difference in terms of gender, fifth and sixth grade students were more positive than eighth grade students, and students with a high average GPA were more positive than those with lower GPAs. On the other hand, there was a low positive relationship between students' teamwork and their decision making inclinations. In addition, it was determined that the students' teamwork inclinations significantly predicted their decision-making inclinations by $4 \%$.
\end{abstract}

Keywords: Teamwork, decision making, gender, grade level, academic success

\title{
Cited:
}

Deveci, İ. (2019). Investigation of middle school students' teamwork and decision making inclinations. Pamukkale Üniversitesi Ë̆itim Fakültesi Dergisi, 47, 311-330. doi: 10.9779/pauefd.525059 


\section{Giriş}

Son yıllarda, öğrencilere 21. yüzyıl yetkinliklerinin kazandırılmasına ilişkin vurgu artmaktadır. 21. yüzyıl yetkinlikleri arasında takım çalışması ve karar verme kavramlarının sıkça telaffuz edildiği görülmektedir. Araştırma Konseyi'nde 21. yüzyıl yetkinlikleri arasında bilişsel yeterlikler arasında karar vermeye ve kişilerarası yeterlikler arasında ise takım çalışmasına vurgu yapılması dikkat çekmektedir (National Research Council, 2012). Diğer taraftan, Department of Education (2003) tarafından hazırlanan dökümanda 21. yüzyıl yetkinlikleri arasında etkili iletişim teması altında takım çalışmasına yer verirken, bilimsel okuryazalık kategorisinde öğrencilerin karar alma eğilimlerinin önemine dikkat çekildiği görülmüştür. Türkiye'de ise Fen bilimleri dersi öğretim programları açısından yaşam beceriler arasında karar verme ve takım çalışması kavramlarına yer verilmesi (Milli Eğitim Bakanlığı [MEB], 2013; MEB, 2017; MEB; 2018a), diğer taraftan 2018 yılı Türkçe Dersi Öğretim Programı'nda kişisel gelişim temasında karar verme ve sosyal gelişime vurgu yapılması (MEB, 2018b), 2018 yılı Beden Eğitimi Ve Spor Dersi Öğretim Programı'nda öğrencilerin kararları arkadaşları ile birlikte alması, grup veya takım ile çözüm üretmelerini sağlamaya yönelik kazanıma yer verilmesi dikkat çekmektedir (MEB, 2018c). Bu gelişmeler ortaokul düzeyindeki öğrencilerin takım çalışması ve karar verme eğilimlerini geliştirmenin önemli olduğunu göstermektedir.

Takım çalışması ve karar verme ile ilgili olarak literatürde bu kavramların beceri, yetenek ve eğilim gibi farklı şekillerde kullanıldığı görülmüştür. Türk Dil Kurumu (TDK) sözlüğünde beceri (skill), bedensel ya da düşünsel bir çaba göstererek bir kimsenin bir işi kolaylık ve ustalıkla yapabilmesi şeklinde tanımlanırken, eğilim (inclination) bir nesneye, bir varlığa karşı duyulan duyguların belirlediği tutum; duyguların etkisiyle belli bir ereğe girişme isteği olarak ifade edilmiştir, bunun yanında yetenek (ability) ise herhangi bir şeyi öğrenmek, bir işi yapmak ve tamamlamak ya da bir duruma başarıyla uymak konusunda organizmada bulunan ve doğuştan gelen güç şeklinde ifade edilmiştir (www.tdk.gov.tr). Mevcut araştırma kapsamında bahsi geçen takım çalışması ve karar verme değişkenleri ile ilgili olarak somut uygulamalara ilişkin incelemenin yapılmaması ve gözleme bağlı süreçlere yer verilmemesinden dolayı beceri ve yetenek kavramının uygun olmadığına karar verilmiştir. Bu araştırmada kullanılan ölçme araçlarının yapısı ve yer verilen ifadelerin daha çok tutum gibi duygusal durumlara yönelik olması ve bu değişkenlere yönelik tercihlerin alınmasından dolayı takım çalışması ve karar verme kavramlarına yönelik "eğilim” ifadesinin daha uygun olduğuna karar verilmiştir. Dolayısıyla metin boyunca takım çalışması ve karar verme için "eğilim" kavramı kullanılmıştır.

\section{Karar Verme Eğilimi}

Karar verme, hangi eylemin gerçekleştirileceğine karar vermekle ilgili olup, genellikle seçenekler arasında seçim yapılmasını gerektirir (Adair, 2007). Karar verme sürecindeki klasik yaklaşım adımları Adair (2007) göre; amaç belirleme, bilgi toplama, uygun seçenekler üretme, karar vermek, uygulama ve değerlendirme şeklinde sıralamıştır. Bu adımları takip ederek bireylerin gerek okul ortamında gerekse günlük hayatta kendi başlarına karar alma eğilimi kazanmalarının amaçlandığı söylenebilir. Nitekim tüm insanları ilgilendiren karar verme, sadece iş yaşamında değil günlük hayatta da kritik öneme sahip olduğuna dikkat çekilmektedir (Rojas, 
Alis ve Londono, 2013). Bu anlamda öğrencilerin erken yaşlarda karar verme eğiliminin fazla olması gelecek yaşantılarında, daha kararlı bireyler konumuna gelmeleri açısından önemli görülebilir.

İlgili literatürde ilkokul ve ortaokul düzeyinde öğrencilerin karar verme eğilimlerinin geliştirilebileceğine yönelik deneysel çalışmalar mevcuttur. Bu çalışmalar arasında en dikkat çeken okul öncesi düzeyinde yürütülen bir araştırma olmuştur. Pekdoğan ve Ulutaş (2018) araştırmalarında okul öncesi karar verme eğitim programının, çocukların karar verme eğilimleri üzerinde olumlu bir etkisi olduğu sonucuna ulaşmıştır. Pekdoğan ve Ulutaş (2018)'in ulaştığı sonuçlar deneysel müdahale ile öğrencilerin karar verme eğilimlerinin erken yaşlarda geliştirilebileceğine işaret etmiştir. Nitekim literatürde ortaokul düzeyinde olumlu sonuçların elde edildiği çok sayıda deneysel çalışma sonuçları görmek mümkündür (Guitiérrez ve GarcíaLópez, 2012; Talaslığlu ve Şahin, 2018; Tetik, 2013). Örneğin; Talaslığlu ve Şahin (2018) deneysel çalışmalarında grafik etkinliklerinin yedinci sınıf öğrencilerinin karar verme eğilimleri üzerinde olumlu bir etkisi olduğu sonucuna ulaşmıştır. Tetik (2013) ise araştırmasında probleme dayalı öğrenmenin dördüncü sınıf öğrencilerinin karar verme eğilimleri üzerinde olumlu bir etkisi olduğu sonucuna ulaşmıştır. Guitiérrez ve García-López (2012) ise oyun temelli etkinliklerin altıncı sınıf ögrencilerinin karar verme eğilimi üzerindeki etkisini inceledikleri araştırmalarında, oyun sonrasında engellerle karşılaşma ve teknik tercihler yapmaları konusunda olumlu etkisi olduğu görülmüştür. Diğer taraftan farklı olarak, Köseoğlu (2014) araştırmasında dördüncü sınıf düzeyinde, drama etkinlikleri ile işlenen derslerin öğrencilerin karar verme eğilimleri üzerinde istatistiksel olarak anlamlı bir fark oluşturmadığını belirlemiştir. Aslında bu deneysel çalışmalar öğrencilerin karar verme eğilimlerinin hangi yöntem ya da tekniklerle geliştirilebileceğine yönelik ip uçları vermektedir. Bunların yanında yürütülen bu deneysel çalışmalar ortaokul düzeyindeki öğrencilerin karar verme eğilimlerinin geliştirilebilmesinin mümkün olduğuna kanıt niteliği taşımaktadır.

Karar verme eğilimleri ile ilgili tarama çalışmalarında, dördüncü sınıf (Tekin ve Ulaş, 2016) ve sekizinci sınıf öğrencilerinin (Bacanlı ve Sürücü, 2006; Gülbahçe ve Kartol, 2014) karar verme eğilimlerini incelemeye yönelik araştırmalara rastlandığı görülmüsstür. Örneğin; Tekin ve Ulaş (2016) araştırmasında dördüncü sınıfta ki kız öğrencilerin bağımsız karar verme eğilimlerinin erkeklere göre daha olumlu olduğunu belirlemiştir. Bunun yanında Tekin ve Ulaş (2016) özel okula giden öğrencilerin, devlet okullarına giden öğrencilere göre, karar verme sürecinde çevresindeki kişilerin fikirlerine önem verme eğilimlerinin daha yüksek olduğunu belirlemiştir. Diğer taraftan sekizinci sınıf öğrencilerinin karar verme stratejileri incelenmiş ve sonuçta erkeklerde sorumluluktan kaçma eğiliminin daha fazla olduğu (Bacanlı ve Sürücü, 2006; Gülbahçe ve Kartol, 2014) ve erkek öğrencilerin aynı zamanda umursamazlıklarının da k1z öğrencilerden daha fazla olduğu (Bacanlı ve Sürücü, 2006) belirlenmiştir. Ocak ve Yurtseven (2016) araştırmasında ise yedinci ve sekizinci sınıf öğrencilerinin karar verme stilleri ile sınav kaygıları arasında ilişkiyi incelemiş ve bu ilişkinin olumlu yönde orta düzeyde olduğunu belirlemiştir. Tarama çalışmalarına dikkat edildiğinde ortaokul öğrencilerinin (5-8. sınıf) sınıf düzeyine bağlı olarak karar verme eğilimlerinin farklılık gösterip göstermeme durumlarını belirlemeye yönelik bir araştırmaya rastlanmamıştır. Böyle bir araştırmanın yürütülmesi ile ortaokulda verilen eğitimin öğrencilerin takım çalı̧̧ması eğilimlerine nasıl yansıdı ğına ilişkin fikir sahibi olmak mümkün olabilir. Bunun yanında ele alınmayan akademik başarı değişkeni açısından da öğrencilerin karar verme eğilimlerinin nasıl bir farklılık 
göstereceği incelenmesi gereken bir boyut olarak karşımıza çıkmaktadır. Son olarak cinsiyet açısından yürütülen araştırmalar olmasına rağmen, bu araştırmaların da sadece belirli sınıf düzeylerinde gerçekleştirildiği görülmüştür (Bacanlı ve Sürücü, 2006; Gülbahçe ve Kartol, 2014). Bu anlamda 5-8. sınıf öğrencilerinin tamamının araştırmaya dahil edilerek öğrencilerin karar verme eğilimlerinin cinsiyet açısından genel durumuna bakılmasının daha isabetli sonuçlar vereceği söylenebilir.

\section{Takım Çalışması Eğilimi}

Eğitim literatüründe takım çalışmasına ekip, komite, küme, grup gibi farklı anlamlar yüklenmektedir (Kocabaş ve Gökbaş, 2003). Bu anlamda takım çalışmasına yönelik farklı tanımlamaların yapıldığı görülmektedir. Mackall (2004)'e göre takım çalışması, bir grup insanın birlikte çalışmak ve ortak bir amacı başarmak için kaynaklarını ve becerilerini bir araya getirmesi süreci olarak görülmektedir. Diğer taraftan Viscuso (2015)'e göre ise takım çalışması ortak bir vizyonu gerçekleştirmeye yönelik grup çalışması yeteneği olarak görülmektedir. Dolayısıyla öğrencilerin grup çalışmasına yönelik tutumlarındaki değişim onların takım çalışması eğilimleri hakkında bilgi vermesi açısından önemli görülebilir. Bu anlamda takım çalışmasına dayalı öğrenme 5-7 kişilik öğrenci grupları ile gerçekleştirilen aktif bir öğretim stratejisi olarak ifade edilmektedir (Altıntaş ve Alimoğlu, 2016).

İlgili literatürde doğrudan ortaokul öğrencilerine yönelik takım çalışması ile ilgili araştırma sayısının oldukça sınırlı olduğu söylenebilir. Bu konuda Deveci (2018) ortaokul öğrencilerinin girişimcilik eğilimlerini incelediği araştırmasında, girişimcilik eğilimi alt faktörlerinden biri olan takım çalışması eğilimlerini de incelemiştir. Deveci (2018) araştırması sonucunda sekizinci sınıf öğrencilerinin takım çalışması eğilimlerinin beşinci ve altıncı sınıf öğrencilerinden daha düşük olduğunu ortaya koymuştur (Deveci, 2018). Bu araştırma sonucunda öğrencilerin takım çalışması eğilimlerinin kapsamlı olarak ele alınması gerektiğine dikkat çekilmiştir. Dolayısıyla mevcut araştırmada doğrudan takım çalışması eğilimlerini belirlemeye yönelik bir ölçme aracı ile ulaşılacak sonuçların önceki araştırma bulguları ile kıyaslanması açısından önemli olduğu söylenebilir. Diğer taraftan takım çalışması ile ilgili araştırmaların daha çok yöneticiler, öğretmenler ve 14-18 yaş sporcu gençler üzerinde yürütüldüğü görülebilir (Ergün ve Eyisoy, 2018; Kocabaş ve Gökbaş, 2003; Tofur ve Balıkç1, 2018). Yürütülen bazı araştırmalarda büyük yaş gruplarında dahi henüz etkili takım çalışması yapılmadığ1 görülmektedir. Örneğin; okullarda öğretmen ve yöneticilerin görüşlerine bağlı olarak takım çalışmasının yerini bireyselliğin almasıyla olumsuz okul ikliminin ortaya çıktığına dikkat çekilmiştir (Tofur ve Balıkçı, 2018). Diğer taraftan, Ayanoğlu ve Hamedoğlu (2013) ilkokul öğretmenlerinin takım algısını incelediği araştırması sonucunda, öğretmenlerin takım çalışması yapmadıkları, bayan öğretmenlerin takım algılarının bay öğretmenlere göre daha olumlu olduğu belirlenmiştir. Aslında öğretmenlerin henüz takım çalışmasına yatkın olmadıklarına ilişkin bulgular göz önüne alındığında (Ayanoğlu ve Hamedoğlu, 2013; Tofur ve Balıkçı, 2018), ortaokul düzeyindeki öğrencilerin takım çalışması eğilimlerinin cinsiyet, sınıf düzeyi ve akademik başarı değişkenlerine göre nasıl bir farklılık göstereceği merak konusudur.

Takım çalışması ile ilgili literatürde daha çok uygulamalı araştırmalarda gerçekleştirilen grup ya da takım çalışmalarına ilişkin olumlu ve olumsuz sonuçlar görmek mümkündür. Örneğin; Aksoy ve Doymuş (2011) altıncı sınıf düzeyinde grup çalışması ya da takım çalışması yapılarak gerçekleştirilen öğretim süreçlerinin öğrencilerin akademik başarılarına olumlu katkısı 
olduğunu belirtmiş̧tir. Ek olarak, uygulamalı araştırmalarda altıncı sınıf öğrencilerinin grup çalışması yapmanın faydalı olduğuna yönelik görüş belirttiklerine dikkat çekilmiştir (Gülen ve Yaman, 2018). Diğer taraftan işbirlikli öğrenme yöntemine dayalı gerçekleştirilen uygulama sonucunda, grup çalışması ile ilgili olarak yedinci sınıf öğrencilerinin grup arkadaşlarıyla sorunlar yaşadıkları, grup üyelerinin yeterli çaba göstermediğine yönelik olumsuz görüşler belirttikleri ortaya çıkmıştır (Bilgin ve Gelici, 2011). Bunların yanında altıncı sınıf öğrencilerinin işbirlikli öğrenme süreçlerinde diğer grup üyeleri tarafından dışlanmak ya da başarısız grup üyeleriyle karşılaşmaktan endişe duydukları belirtilmiştir (Altun, 2017). Aslında ortaokul düzeyinde grup çalışması ve takım çalışması süreçlerine gerek yöntemsel açıdan (işbirlikli öğrenme) gerekse etkinliklerin yapılış şekli itibariyle sürekli olarak başvurulmaktadır. $\mathrm{Bu}$ kadar sık başvurulan takım çalışması süreçleri açısından öğrencilerin bu süreçlere ilişkin eğilimlerinin cinsiyet, sınıf düzeyi ve akademik başarı değişkenleri açısından nasıl bir farklılık göstereceğinin belirlenmesi gerektiği söylenebilir.

\section{Takım Çalışması ve Karar Verme Eğilimi}

Literatürde işbirlikli grup çalışmalarının akademik başarı üzerinde olumlu etkisi olduğunu ortaya koyan çalışma olduğu gibi (Slavin, Hurley ve Chamberlain, 2003), sorumluluğun öğrencide olduğu durumlarda, bireysel çalışma yapan öğrencilerin grup çalışması yapan öğrencilere göre daha başarılı olduklarını (Arslan, Taşkın ve Kirman-Bilgin, 2015) ortaya koyan araştırmalarda mevcuttur. Bu anlamda takım çalışması temel alınarak gerçekleştirilen süreçlerde ortaya çıkacak olumsuzlukların belirlenmesi ve incelenmesi, takım çalışmalarının daha nitelikli yürütülmesinin önünü açabilir. Takım çalışması sürecinde amaçlardan biri de öğrencilerin ortak bir karara varmasıdır (Lawrence-Brown ve Muschaweck, 2004). Böylelikle işbirlikli grup çalışmalarında öğrenciler problemleri çözmek için ortak bir karar verme sürecine dahil olmaktadır (Hobbs ve Westling, 1998). Güneş ve Asan (2005) grup çalışması sürecinde grup üyelerinin birbirlerini olumsuz etkileyebileceğine de dikkat çekmektedir. $\mathrm{Bu}$ olumsuz durumlardan birinin de karar verme süreci olduğu söylenebilir. Bu anlamda tam olarak takım çalışması ruhunun yer almadığı grup çalışmalarında karar alma süreçlerinin verimsiz olacağına dikkat çekilmektedir (Stacey, 2009). Dolayısıyla grup çalışması sürecinde öğrencilerin en fazla zorlandıkları boyutlardan birinin de "karar verme" süreci olduğunu söylemek mümkündür. Öğrenciler karar vermekte zorlandıkları gibi ortak karar verme noktasında da zorluk yaşayarak grupları adına karar verici öğretmen ya da dış faktörlere başvurmayı tercih etmektedir. Bu anlamda Galton ve Williamson (1992) grup çalışmaları yürütürlürken, grup kararlarının alındığı süreçlerde öğretmene olan bağımlılığın azaltılması gerektiğini vurgulamaktadır. Aslında bu durum takım çalışması etkinliklerinin iyi planlanmadığında olumsuz sonuçlar doğurabileceğine işaret etmektedir. Buradan yola çıkarak; öğrencilerin takım çalışması eğilimleri ile karar verme eğilimleri arasında nasıl bir ilişki vardır? Sorusu gün yüzüne çıkmaktadır. Bu anlamda öğrencilerin takım çalışması eğilimi ile karar verme eğilimi arasındaki ilişkinin yönü, düzeyi ve bu iki değişkenin bir birini yordama durumunun incelenmesi gerektiği söylenebilir.

$\mathrm{Bu}$ araştırmanın amacı; öğrencilerin takım çalışması ve karar verme eğilimlerini çeşitli değişkenler açısından incelemek, bunun yanında takım çalışması ile karar verme eğilimi arasındaki ilişkiyi belirlemektir. Bu doğrultuda çalışmanın alt problemleri aşağıda gibi oluşturulmuştur. 
-Öğrencilerin takım çalışması eğilimleri akademik başarı, cinsiyet ve sınıf düzeyi değişkenleri açısından istatistiksel olarak anlamlı bir farklılık göstermekte midir?

-Öğrencilerin karar verme eğilimleri akademik başarı, cinsiyet ve sınıf düzeyi değişkenleri açısından istatistiksel olarak anlamlı bir farklılık göstermekte midir?

-Öğrencilerin takım çalışması eğilimleri ile karar verme eğilimleri arasındaki korelasyonel ilişkinin yönü ve düzeyi nedir?

-Öğrencilerin takım çalışması eğilimleri, karar verme eğilimlerini istatistiksel olarak anlamlı bir şekilde yordamakta mıdır?

\section{Yöntem}

Deneysel olmayan nicel yaklaşımların tercih edildiği bu araştırmada; nedensel-karşılaştırmalı (causal-comparative research) ve korelasyonel araştırma (correlational research) tasarımları kullanılmıştır. Nedensel-karşılaştırmalı araştırmalarda, bağımsız değişkenlerin bağımlı değişken üzerinde bir değişime neden olup olmadığını görmek için grupları karşılaştırma durumu söz konusudur (Lodico, Spaulding ve Voegtle, 2006). Bu araştırmada nedensel-karşılaştırmalı araştırma tasarımı sayesinde bağımsız değişkenler olan cinsiyet, sınıf düzeyi ve akademik başarının; bağımlı değişkenler olan karar verme ve takım çalışması eğilimleri üzerinde istatistiksel olarak anlamlı bir farklılık oluşturup oluşturmadığ incelenmiştir. Diğer taraftan korelasyonel araştırmalarda, korelasyon katsayısına bağlı ilişkisel tasarımlar (relationship studies) ve bağımlı değişken üzerindeki değişimi yordayan bağımsız değişkenleri keşfetmeye yönelik tahmin çalışmaları (prediction studies) kullanılmaktadır (Lodico, Spaulding ve Voegtle, 2006). Dolayısıyla bu araştırmada öğrencilerin takım çalışması ve karar verme eğilimleri arasındaki ilişkinin düzeyi ve yönünü incelemek için ilişkisel tasarımdan, bunun yanında karar verme eğiliminin takım çalışması eğilimini yordama durumunu incelemek için tahmin çalışması tasarımından yararlanılmıştır.

\section{Evren ve Örneklem}

Araştırma verileri 2018 y1lı içerisinde Kahramanmaraş İli'nde elde edilmiştir. Üç ortaokulda öğrenim gören, A kodlu ortaokuldan 169 öğrenci, B kodlu ortaokuldan 165, ve C kodlu ortaokuldan 188 öğrenci olmak üzere toplam 522 öğrenci araştırmaya dahil edilmiştir. Bu araştırmada zaman sınırlılı̆̆ ve uzaklık sorunu nedeniyle verilerin araştırmacının kontrolünde toplanmasını mümkün kılmak için kolay ulaşılabilir örnekleme yönteminden yararlanılmıştır (Lodico, Spaulding ve Voegtle, 2006). Araştırmada örneklemin yeterli olup olmadığına ilişkin olarak, evren 5.000 veya daha fazla sayıda ise 350 ile 500 kişilik örneklem sayısının yeterli olduğu belirtilmiştir (Lodico, Spaulding ve Voegtle, 2006). Bu araştırmaya dahil edilen 5-8. sınıf ortaokul öğrencilerinin Kahramanmaraş ilindeki sayısının 5.000 fazla olması, örneklem sayısının yeterli olduğunu göstermektedir. Tablo 1'de örnekleme ait bilgiler verilmiştir.

Tablo 1. Örnekleme Ait Bilgiler

\begin{tabular}{cccc}
\hline Kategoriler & Alt Ketegoriler & N & Toplam \\
\hline \multirow{2}{*}{ Cinsiyet } & Kız & 254 & 522 \\
& Erkek & 268 & \\
\multirow{2}{*}{ Sinıf Düzeyi } & Beşinci sinıf & 145 & 522 \\
& Altıncı sınıf & 125 & \\
& Yedinci sınıf & 123 & \\
\hline
\end{tabular}




\begin{tabular}{lccc}
\hline & Sekizinci sınıf & 129 & \\
& $0-69$ puan aralığı & 116 & 522 \\
Akademik Başarı Ortalaması & $70-84$ puan aralığı & 153 & \\
& 85 ve üzeri puan aralığı & 253 & \\
\hline
\end{tabular}

\section{Veri Toplama Araçları}

$\mathrm{Bu}$ araştırmada veriler karar verme ölçeği ve grup çalışması ölçeğinden yararlanılarak elde edilmiştir.

\section{Karar Verme Ölçeği}

$\mathrm{Bu}$ ölçme aracı ilkokul ve ortaokul öğrencilerinin günlük yaşamda karşılaştıkları problemleri çözmeye yönelik karar verme eğilimlerini ölçmek amacıyla Karakaş (1999) tarafindan geliştirilmiştir. Ölçme aracında yedi olumsuz $(1,2,3,4,5,6$ ve 16. maddeler) ve diğerleri olumlu olmak üzere 17 madde bulunmaktadır. Ölçme aracında yer alan maddeler 4-1 arasında her zamandan hiçbir zamanada doğru derecelendirilmiştir. Ölçme aracında yer alan faktörler ve Cronbach alpha katsayıları; bağımsız karar verme $(\alpha=.47)$, bağımlı karar verme $(\alpha=.65)$, yeteneklerine göre karar verme $(\alpha=.48)$ ve isteklerini göz önüne alarak karar verme $(\alpha=.55)$ şeklindedir. Araştırmada ölçeğin tamamına ilişkin Cronbach alpha değeri belirtilmeyip, faktör düzeyindeki Cronbach alpha katsayılarının düşük olduğu söylenebilir. Bu anlamda Tayran ve Ulupınar (2011) belirttiği gibi çok faktörlü ölçeklerde faktörlerde yer alan madde sayılarının az olması Cronbach alfa değerlerinin daha düşük değerler almasına yol açmış olabilir. Diğer taraftan bu ölçme aracının farklı araştırmalarda da kullanılması ölçeğin kullanılabilir düzeyde geçerli ve güvenilir bir ölçme aracı olduğuna işaret etmektedir (Çakmakçı, 2009; Köseoğlu, 2014; Tekin ve Ulaş, 2016). Örneğin; Çakmakçı (2009) bu ölçme aracını kullandığ1 araştırmasında güvenirliği .65 ve Köseoğlu (2014) ise araştırmasında 70 olarak bulmuştur. Mevcut araştırmada ise ölçeğin geneline ilişkin Cronbach alpha güvenirlik katsayısı .45 olarak bulunmuştur.

\section{Grup Çalışması Ölçeği}

$\mathrm{Bu}$ ölçme aracı ortaokul öğrencilerinin grup çalışmasına yönelik tutumlarını incelemek amacıyla Yılmaz, Baydaş ve Kokoç (2017) tarafından geliştirilmiştir. 20 maddeden oluşan ölçme aracında, maddelerden beşinin olumsuz $(16,17,18,19$ ve 20 . maddeler) diğerlerinin ise olumlu maddeler olduğu görülmüştür. Ölçme aracında yer alan maddelere ilişkin seçenekler 5'li Likert tipinde derecelendirilmiştir. Ölçme aracında yer alan faktörler ve güvenirlik katsayılarının; bireysel katk1 ve kazanım ( $\alpha=.75)$, ürün ve sürecin kalitesi $(\alpha=.76)$, grup içi etkileşim $(\alpha=.70)$ ve grup içi çatışması $(\alpha=.63)$ olduğu görülmüştür. Bu anlamda ölçme aracının geçerli ve güvenilir olduğu söyenebilir. Mevcut araştırmada ise ölçeğin geneline ilişkin Cronbach alpha güvenirlik katsayısı .73 olarak bulunmuştur.

\section{Uygulama Süreci}

Verilerin elde edildiği süreçte öncelikle ölçekler çoğaltılmış ve ardından üç farklı ortaokulda uygulanmıştır. Uygulama sürecinde öğrencilere gönüllü olarak doldurmaları gerektiği, doldurmak istemeyenlere hiçbir yaptırım uygulanmayacağı açık bir şekilde ifade edilmiştir. Ölçek formları üzerinde öğrencilerin kimliğini açığa çıkaracak herhangi bir bilgiye yer verilmemiştir. Uygulamalar ders süresini aksatmayacak şekilde ders öğretmenleri ve 
araştırmacının kontrolü altında gerçekleştirilmiştir. Öğrenciler ölçeklere ortalama $20 \mathrm{dk}$ süre ayırmıştır.

\section{Verilerin Analizi}

Araştırma verilerinin analiz edildiği süreçte ilk olarak her bir öğrencinin ölçek maddelerine ilişkin verdiği yanıtlar istatistiksel paket programına aktarılmıştır. Daha sonra yanlış verişi girişi olup olmadığı kontrol edilmiştir. İstatistik paket programına yanlış girildiği tespit edilen 10 ölçek verileri, ölçek formu ile karşılaştırılarak düzeltilmiştir. Ardından kayıp değerler incelenmiş ve kayıp değerlerin \%5 altında olduğu belirlenmiştir. Bu araştırmada kayıp veriler yerine yaklaşık değer atamada gelişmiş yöntemlerden biri olarak (Çüm ve Gelbal, 2015), eksik değerleri olmayan yeni bir veri kümesi oluşturmaya yönelik (Acock, 2005) beklenti maximizasyonu ile değer ataması gerçekleştirilmiştir. Bu şekilde veriler analize hazır hale getirilmiştir.

Bu çalışmanın bağımsız değişkenleri, öğrencilerin cinsiyeti (kız / erkek), sınıf düzeyi (beşinci, altınc1, yedinci ve sekizinci sınıf) ve akademik başarıdan (0-69, 70-84, 85-100 not ortalaması) oluşmaktadır. Araştırmanın bağımlı değişkenleri ise karar verme ve takım çalışması eğilimlerinden oluşmaktadır. Bu şekilde üç bağımsız değişken ve iki bağımlı değişkenin aynı anda analize dahil edilmesini sağlayan üç yol MANCOVA analizi gerçekleştirilmiştir. Aslında bu araştırmada her bir bağımlı değişken için bağımsız değişkenlere göre farklılıkları ayrı ayrı ANCOVA analizi ile gerçekleştirmekte mümkündür. Ancak bu yol ayrı ayrı yürütülen analiz işlemlerindeki \% 5'lik hata payının artmasına ve Tip 1 hata'ya yol açmaktadır. Bu hataya yol açmamak için üç yol MANCOVA ile bağımlı ve bağımsız değişkenlerin aynı anda analize edilmesi sağlanmıştır (Cronk, 2008; Pallant, 2007). İkiden fazla bağımsız değişken kategorilerinde görülen istatistiksel anlamlı farklılığın hangi grup lehine olduğunu incelemek için Post Hoc testlerinde yer alan Tukey testi ile incelenmiştir (Page, Braver ve MacKinnon, 2003). Daha sonra korelasyon analizinden yararlanılarak takım çalışması ve karar verme eğilimleri arasındaki ilişkinin derecesi ve yönü ikili (basit) korelasyona bağlı Pearson korelasyon katsayısı ile incelenmiştir. Son olarak, basit doğrusal regresyon analizinden yararlanılarak bağımsız değişken olarak ele alınan takım çalışması eğilimlerinin bağımlı değişken olarak ele alınan karar verme eğilimlerini yordama durumu incelenmiştir.

MANOVA analizi gerçekleştirilmeden önce bu analizin varsayımları karşılanmıştır. Pallant (2007)'e göre MANOVA analizi varsayımları örneklem büyüklüğü, normal dağılım, uç değerlerler, doğrusallık (Linearity), çoklu bağlantılılık ve tekillik (Multicollinearity and singularity) ve son olarak varyansların homojenliği (Homogeneity of variance-covariance matrices) şeklindedir. Bu varsayımlara yönelik öncelikle örneklem büyüklüğü varsayımı incelenmiş ve mevcut araştırmada 522 kişiden oluşan örneklem büyüklügünün yeterli olduğu belirlenmiştir (Lodico, Spaulding ve Voegtle, 2006). Daha sonra normal dağılım varsayımı incelenmiş ve karar verme değişkeni için basıklık (kurtosis) değeri -0.368, çarpıklık (skewness) değeri 0.008 bulunurken, takım çalışması değişkeni için basıklık değeri -0.113, çarpıklık değeri ise -0.194 bulunmuştur. Çarpıklık ve basıklık değerlerinin \pm 1.0 arasında olması normal dağılım için yeterli bir ölçüt olarak kabul edilmektedir (George ve Mallery, 2016). Tek değişkenli uç değerler açısından, analiz işlemlerine geçmeden önce uç değerler incelenmiş ve uç değer olduğu belirlenen 15 veri seti analize dahil edilmemiştir. Çok değişkenli normallik varsayımı için ise Mahalanobis uzaklığı incelenmiş ve Mahalanobis uzaklıklarının en küçük 1.25 ve en yüksek 
6.29 değeri aldığı görülmüştür. Üç bağımsız değişken için Mahalanobis uzaklıklarının sınır değerinin 16.27 olduğu dikkate alındığında bu araştırma için çok değişkenli normallik varsayımının karşılandığı söylenebilir (Tabachnick ve Fidell, 2007; Pallant, 2007). Bağımlı değişkenler arasında doğrusal bir ilişki olup olmadığı hem serpilme grafiği (Scatter Plot) hem de değişkenler arasındaki korelasyon katsayısına bakılarak incelenmiştir. Gerek saçılma grafiği sonucu $\left(\mathrm{R}^{2}\right.$ linear $\left.=0.036\right)$ ve bağımlı değişkenler arasındaki korelasyonun 0.19 olması $(\mathrm{p}<.05)$ ve 0.90 'dan küçük olması bu bağımlı değişkenler arasında çoklu bağlantılılığın (multi collinear) olmadığını göstermektedir (Pallant, 2007). MANOVA varsayımlarına ilişkin son olarak Levene testi ile karar verme $(\mathrm{F}=0.819, \mathrm{p}>.05)$ ve takım çalışması $(\mathrm{F}=1.163, \mathrm{p}>.05)$ değişkenlerine ilişkin varyansların homojen dağıldığı görülmüştür. Diğer taraftan Box's $\mathrm{M}$ testi sonucunda bağımlı değişkenlerin gözlenen kovaryans matrislerinin gruplar arasında eşit olduğu tespit edilmiştir $(\mathrm{F}=1.135, \mathrm{p}>.05)$. Son olarak araştırmada istatistiksel analizlerde anlamlılık düzeyi 0.05 (\% 95 güven aralı̆̆ı) olarak belirlenmiştir.

\section{Bulgular ve Yorum}

Araştırma bulguları iki temel başlıkta sunulmuştur. Birinci temel başlıkta, öğrencilerin takım çalışması ve karar verme eğilimlerinin sınıf düzeyi, cinsiyet ve akademik başarı değişkenlerine göre analiz bulguları birlikte sergilenmiştir. İkinci temel başlıkta, öğrencilerin takım çalışması ve karar verme eğilimleri arasındaki ilişki, son olarak ise öğrencilerin takım çalışması eğilimlerinin karar verme eğilimlerini yordama durumuna ilişkin bulgular sergilenmiştir.

Öğrencilerin Takım Çalışması ve Karar Verme Eğilimlerinin Sınıf Düzeyi, Cinsiyet ve Akademik Başarı Değişkenlerine Göre İncelenmesine Yönelik Bulgular

Araştırmada takım çalışması ve karar verme eğilimlerinin sınıf düzeyi, cinsiyet ve akademik başarı değişkenlerine göre analiz bulgularında, öncelikle MANCOVA bulguları incelenmiştir. Tablo 2'de MANCOVA analizi sonucunda elde edilen bulgular verilmiştir.

Tablo 2. Bağımsız Değişkenler Açısından Bağımlı Değişkenlere İlişkin MANCOVA Bulguları

\begin{tabular}{ccccccc}
\hline Varyans Kaynağı & $\begin{array}{c}\text { Wilks’ } \\
\text { lambda }\end{array}$ & F & $\begin{array}{c}\text { Hipotez } \\
\text { Serbestlik } \\
\text { derecesi (df) }\end{array}$ & $\begin{array}{c}\text { Hata Serbestlik } \\
\text { derecesi(df) }\end{array}$ & P & Eta Kare \\
\hline Cinsiyet & .960 & 10.612 & 2.000 & 514.000 & $.000^{*}$ & .040 \\
Sınıf Düzeyi & .943 & 5.129 & 6.000 & 1028.000 & $.000^{*}$ & .029 \\
Akademik başarı & .943 & 7.714 & 4.000 & 1028.000 & $.000 *$ & .029 \\
\hline
\end{tabular}

$* \mathrm{p}<.05$

MANCOVA sonuçlarına göre karar verme ve takım çalışması eğilimlerinin öğrencilerin cinsiyet açısından (Wilks' Lambda $=.96, \mathrm{~F}=10.61, \mathrm{df}=[2,514], \mathrm{p}<.05$ ), sınıf düzeyi açısından (Wilks' Lambda $=.94, \mathrm{~F}=5.129, \mathrm{df}=[6,1028], \mathrm{p}<.05)$ ve akademik başarı açısından (Wilks' Lambda $=.94, \mathrm{~F}=7.714, \mathrm{df}=[4,1028], \mathrm{p}<.05)$ anlamlı bir farklılık gösterdiği belirlenmiştir. Bağımsız değişkenlerin ayrı ayrı bağımlı değişkenler üzerindeki etkisini görmek için, her bir bağımlı değişkene yönelik ANCOVA bulguları Tablo 3’te verilmiştir. 
Tablo 3. Bağımsız Değişkenler Açısından Her Bir Bağımlı Değişkene Yönelik ANCOVA Bulguları

\begin{tabular}{cccccccc}
\hline \multirow{2}{*}{ Kaynak } & \multirow{2}{*}{ Bağımlı Değişkenler } & $\begin{array}{c}\text { Karelerin } \\
\text { Toplamı }\end{array}$ & $\begin{array}{c}\text { Serbestlik } \\
\text { derecesi }\end{array}$ & $\begin{array}{c}\text { Kareler } \\
\text { Ortalaması }\end{array}$ & F & P & \multicolumn{2}{c}{ Kısmi Eta- } \\
Kare
\end{tabular}
$* \mathrm{p}<.05$

ANCOVA sonuçlarına bakıldığında öğrencilerin karar verme eğilimlerinin cinsiyet değişkenine göre istatistiksel olarak anlamlı bir farklılık gösterdiği belirlenirken $(\mathrm{F}=21.225$; $\mathrm{p}<.05$ ), takım çalışması eğilimlerinin cinsiyet değişkenine göre istatistiksel olarak anlamlı bir farklılık göstermediği belirlenmiştir $(\mathrm{F}=1.061 ; \mathrm{p}>.05)$. Sınıf düzeyi açısından bakıldığında öğrencilerin hem karar verme eğilimlerinin $(\mathrm{F}=4.647 ; \mathrm{p}<.05)$ hem de takım çalışması eğilimlerinin $(\mathrm{F}=4.206 ; \mathrm{p}<.05)$ sinıf düzeyine göre istatistiksel olarak anlamlı bir farklılık gösterdiği belirlenmiştir. Benzer şekilde öğrencilerin hem karar verme eğilimlerinin ( $\mathrm{F}=11.091$; $\mathrm{p}<.05)$ hem de takım çalışması eğilimlerinin $(\mathrm{F}=6.272 ; \mathrm{p}<.05)$ akademik başarı değişkenine göre istatistiksel olarak anlamlı bir farklılık gösterdiği belirlenmiştir. Bu aşamadan sonra istatistiksel olarak anlamlı farklılığın gözlendiği bağımsız değişken grupları incelenmiştir. İlk olarak cinsiyet değişkeni açısından bulgular Tablo 4'te verilmiştir.

Tablo 4. Cinsiyet Değişkeni Açısından Analiz Sonuçları

\begin{tabular}{|c|c|c|c|c|c|c|}
\hline \multirow{2}{*}{ Bağımlı Değişkenler } & \multirow{2}{*}{$\begin{array}{l}\text { Bağımsız } \\
\text { değişken }\end{array}$} & \multirow{2}{*}{ Ort } & \multirow{2}{*}{$\begin{array}{c}\text { Standart } \\
\text { hata }\end{array}$} & \multirow{2}{*}{$\mathrm{P}$} & \multicolumn{2}{|c|}{$95 \%$ güven aralığ1 } \\
\hline & & & & & Alt sinir & Üst sınır \\
\hline \multirow{2}{*}{ Karar verme } & Erkek & 2.854 & .018 & \multirow{2}{*}{$.000 *$} & 2.819 & 2.889 \\
\hline & $\mathrm{K}_{1 Z}$ & 2.968 & .018 & & 2.933 & 3.004 \\
\hline \multirow{2}{*}{ Takım Çalışması } & Erkek & 3.789 & .028 & \multirow{2}{*}{.303} & 3.735 & 3.843 \\
\hline & $\mathrm{K}_{1 \mathrm{Z}}$ & 3.829 & .028 & & 3.774 & 3.885 \\
\hline
\end{tabular}

*p<.05

Tablo 4'te görüldüğü gibi karar verme eğilimi açısından kız öğrencilerin puan ortalamalarının (2.96) erkek öğrencilerin puan ortalamalarından (2.85) istatistiksel olarak anlamlı düzeyde daha fazla olduğu görülmüştür $(\mathrm{P}<.05)$. Diğer taraftan takım çalışması eğilimi açısından kız öğrencilerin puan ortalamaları (3.82) ile erkek öğrencilerin puan ortalamaları (3.79) arasında istatistiksel olarak anlamlı farklılık gözlenmemiştir ( $\mathrm{p}>.05)$.

Sınıf düzeyi açısından gözlenen istatistiksel olarak anlamlı farklılığın hangi gruplar arasında olduğunu belirlemek için ikiden fazla grup için Post Hoc sonuçları incelenmiştir. Tablo 5 'te sınıf düzeyi açısından Tukey testi sonuçları verilmiştir. Tukey testi sonuçlarına göre yedinci sınıf (2.95) öğrencilerinin karar verme eğilimi puan ortalamalarının beşinci sınıf (2.84) öğrencilerinin karar verme eğilimi puan ortalamalarından istatistiksel olarak anlamlı düzeyde daha yüksek olduğu görülmüştür ( $\mathrm{p}<.05)$. Takım çalışması eğilimi açısından ise beşinci (3.86) ve altıncı (3.87) sınıf öğrencilerinin takım çalışması eğilimi puan ortalamalarının sekizinci sınıf (3.69) öğrencilerinin takım çalışması eğilimi puan ortalamalarından istatistiksel olarak anlamlı düzeyde daha yüksek olduğu görülmüş̧ür $(\mathrm{p}<.05)$. 
Tablo 5. Sınıf Düzeyine Göre Tukey Testi Sonuçları

\begin{tabular}{|c|c|c|c|c|c|c|c|}
\hline \multirow{2}{*}{$\begin{array}{c}\text { Bağımlılı } \\
\text { Değişkenler }\end{array}$} & \multirow{2}{*}{$\begin{array}{l}\text { Sinıf Düzeyi } \\
\text { (a) }\end{array}$} & \multirow{2}{*}{ Sınıf Düzeyi (b) } & \multirow{2}{*}{$\begin{array}{l}\text { Ortalama } \\
\text { Fark1 (a-b) }\end{array}$} & \multirow{2}{*}{$\begin{array}{c}\text { Standart } \\
\text { hata }\end{array}$} & \multirow{2}{*}{$\mathrm{P}$} & \multicolumn{2}{|c|}{$95 \%$ güven aralığı } \\
\hline & & & & & & Alt sınır & Üst sinır \\
\hline \multirow{3}{*}{ Karar Verme } & \multirow{3}{*}{ Beşinci sınıf } & Altınc1 Sinıf & -.0628 & .03430 & .260 & -.1512 & .0256 \\
\hline & & Yedinci Sınıf & $-.1048 *$ & .03445 & $.013 *$ & -.1935 & -.0160 \\
\hline & & Sekizinci sınıf & -.0799 & .03401 & .089 & -.1675 & .0078 \\
\hline \multirow{3}{*}{ Takım Çalışması } & \multirow{3}{*}{$\begin{array}{l}\text { Sekizinci } \\
\text { sinıf }\end{array}$} & Beşinci sınıf & $-.1800 *$ & .05273 & $.004 *$ & -.3159 & -.0441 \\
\hline & & Altınc1 Sinif & $-.2128 *$ & .05468 & $.001 *$ & -.3538 & -.0719 \\
\hline & & Yedinci Sinıf & -.1123 & .05491 & .173 & -.2538 & .0292 \\
\hline
\end{tabular}

Diğer taraftan akademik başarı açısından gözlenen anlamlı farklılığın hangi gruplar arasında olduğunu belirlemek için ikiden fazla gruplar için Post Hoc sonuçları incelenmiştir. Tablo 6' da akademik başarı açısından Tukey testi sonuçları verilmiştir.

Tablo 6. Akademik Başarıya Göre Tukey Testi Sonuçları

\begin{tabular}{cccccccc}
\hline $\begin{array}{c}\text { Bağımlı } \\
\text { Değişkenler }\end{array}$ & $\begin{array}{c}\text { Akademik } \\
\text { başarı (a) }\end{array}$ & $\begin{array}{c}\text { Akademik } \\
\text { başarı (b) }\end{array}$ & $\begin{array}{c}\text { Ortalama } \\
\text { Farkı (a-b) }\end{array}$ & $\begin{array}{c}\text { Standart } \\
\text { hata }\end{array}$ & P & \multicolumn{2}{c}{$95 \%$ güven aralığı } \\
Karar Verme & \multirow{2}{*}{85 ve üzeri } & $0-69$ & $.1570^{*}$ & .03151 & $.000^{*}$ & .0830 & .2311 \\
& & $70-84$ & $.0849^{*}$ & .02878 & $.009^{*}$ & .0172 & .1525 \\
Takım Çalışması & $0-69$ & $70-84$ & $-.1989^{*}$ & .05364 & $.001^{*}$ & -.3250 & -.0728 \\
& & 85 ve üzeri & $-.2001^{*}$ & .04885 & $.000^{*}$ & -.3149 & -.0853 \\
\hline
\end{tabular}

$* \mathrm{p}<.05$

Tablo 6'da verilen Tukey testi sonuçlarına göre akademik ortalaması 85 ve üzeri (2.99) öğrencilerin, akademik ortalaması 0-69 (2.83) ve 70-84 (2.91) arasında olan öğrencilere göre karar verme eğilimi puan ortalamalarının istatistiksel olarak anlamlı düzeyde daha yüksek olduğu görülmüştür $(\mathrm{p}<.05)$. Takım çalışması eğilimi açısından bakıldığında, akademik ortalamas1 85 ve üzeri (3.85) olan öğrenciler ile 70 - 84 (3.88) arasında olan öğrencilerin, akademik ortalaması 0-69 (3.70) arasında olan öğrencilere göre takım çalışması eğilimi puan ortalamalarının istatistiksel olarak anlamlı düzeyde daha yüksek olduğu görülmüştür $(\mathrm{p}<.05)$.

\section{Ortaokul Öğrencilerinin Takım Çalışması ve Karar Verme Eğilimleri Arasındaki Korelasyona Yönelik Bulgular}

$\mathrm{Bu}$ bölümde öncelikle takım çalışması ve karar verme eğilimleri arasında ilişkinin yönü ve derecesi basit korelasyon analizi incelenmiştir. Daha sonra bağımsız değişken olarak ele alınan takım çalışması eğilimlerinin karar verme eğilimlerini yordama durumuna ilişkin basit doğrusal regresyon analizi bulgularına yer verilmiştir. Bu doğrultuda ilk olarak takım çalışması ve karar verme eğilimleri arasındaki basit korelasyon değerleri Tablo 7'de verilmiştir.

Tablo. 7. Takım Çalışması ve Karar Verme Eğilimleri Arasındaki Basit Korelasyon Analizi Sonuçları

\begin{tabular}{clcc}
\hline & Değişkenler & Takım çalışması & $\mathrm{P}$ \\
\hline Pearson korelasyon katsayıs1 & Karar verme & .190 & $0.000^{*}$ \\
\hline *p $<.05$ & & &
\end{tabular}

Tablo 7'de verilen korelasyon değerleri incelendiğinde öğrencilerin karar verme eğilimleri ile takım çalışması eğilimleri arasında istatistiksel olarak anlamlı düzeyde pozitif 
yönlü düşük düzeyde bir ilişki olduğu görülmüştür $(\mathrm{r}=0.19 ; \mathrm{p}<.05)$. Tablo 8 'de öğrencilerin takım çalışması eğilimlerinin karar verme eğilimlerini yordayıp yordamama durumuna ilişkin analiz sonuçlarına yer verilmiştir.

Tablo 8. Öğrencilerin Takım Çalışması Eğilimlerinin Karar Verme Eğilimlerini Yordama Durumuna İlişkin Basit Doğrusal Regresyon Analizi Sonuçları

\begin{tabular}{cccccccc}
\hline Değişken & $\mathrm{B}$ & $\mathrm{t}$ & $\begin{array}{c}\text { Standart } \\
\text { hata }\end{array}$ & $\mathrm{R}^{2}$ & $\begin{array}{c}\text { Standardize } \\
\text { edilmiş } \beta\end{array}$ & $\mathrm{F}$ & $\mathrm{P}$ \\
\hline Sabit & 2.448 & 22.305 & 0.290 & 0.036 & 0.190 & 19.551 & $0.000^{*}$ \\
Takım çalışması & 0.126 & 4.422 & & & & &
\end{tabular}

Tablo 8'de yer alan veriler incelendiğinde, öğrencilerin takım çalışması eğilimlerinin,

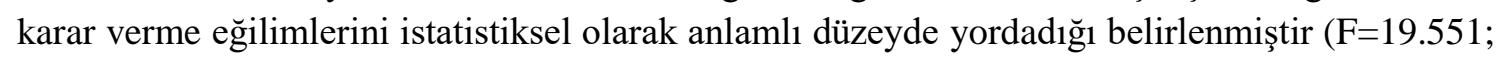
$\mathrm{p}<.05)$. Dolayısıyla öğrencilerin takım çalışması eğilimlerinin karar verme eğilimlerindeki değişimin \% 4'ünü açıkladığı görülmektedir $\left(\mathrm{R}^{2}=0.036 ; \mathrm{P}<.05\right)$.

\section{Tartışma ve Sonuç}

Araştırmada öğrencilerin takım çalışması ve karar verme eğilimleri cinsiyet, sınıf düzeyi ve akademik başarı değişkenlerine göre analiz edilmiştir. Ayrıca öğrencilerin takım çalışması ve karar verme eğilimleri arasındai ilişki incelenmiştir. Araştırma bulguları da bu doğrultuda ayrı ayrı tartışılmış ve sonuçlandırılmıştır.

Öncelikle öğrencilerin takım çalışması ve karar verme eğilimleri cinsiyet değişkeni açısından incelenmiştir. Böylece kız öğrencilerin erkek öğrencilere göre karar verme eğilimlerinin istatistiksel olarak anlamlı düzeyde daha fazla olduğu görülmüştür. Buradan yola çıkarak kız öğrencilerin karar alma sürecinde dış faktörlerden erkek öğrencilere göre daha az etkilendikleri söylenebilir. Bu iddiayı destekler nitelikte sekizinci sınıf erkek öğrencilerin karar verme sürecinde kız öğrencilere göre sorumluluk almaktan kaçındıkları (Bacanlı ve Sürücü, 2006; Gülbahçe ve Kartol, 2014), dördüncü sınıf kız öğrencilerin bağımsız karar verme eğilimlerinin erkeklere göre daha yüksek olduğu (Tekin ve Ulaş, 2016) ve sekizinci sınıf erkek öğrencilerdeki umursamazlığın kız öğrencilere göre daha fazla olduğu belirlenmiştir (Bacanlı ve Sürücü, 2006). Farklı bir öğrenci profili olan 5-8. sınıf üstün yetenekli öğrenciler üzerinde gerçekleştirilen bir çalışmada da, kız öğrencilerin karar verme eğilimlerinin erkek öğrencilerden istatistiksel olarak anlamlı ölçüde daha fazla olduğu görülmüştür (Ersoy ve Deniz, 2016). Gerek mevcut araştırma sonuçları gerekse ilgili literatürde yer alan araştırma sonuçları, kız öğrencilerin erkek öğrencilere göre karar verme eğilimlerinin daha olumlu olduğunu göstermiştir. Diğer taraftan cinsiyet açısından öğrencilerin takım çalışması eğilimleri istatistiksel olarak anlamlı bir farklılık göstermemiştir. Ancak kız öğrencilerin takım çalışması eğilimi toplam puan ortalamalarının erkek öğrencilerden daha fazla olduğu belirlenmiştir. İlgili literatürde ortaokul öğrencilerinin doğrudan takım çalışması eğilimlerini incelemeye yönelik bir araştırmaya rastlanmamıştır. Bazı araştırmalarda kullanılan veri toplama araçlarının faktörlerinden birinin takım çalışması eğilimi olduğu görülmüştür. Örneğin Deveci (2018) öğrencilerin girişimcilik eğilimlerini incelediği araştırmasında, takım çalışması faktöründe kız ve erkek öğrencilerin takım çalışması eğilimleri arasında anlamlı bir fark olmamasına rağmen kız öğrencilerin takım çalışması toplam puan ortalamalarının erkek öğrencilerden daha fazla olduğunu belirlemiştir. Sonuç olarak takım çalışması açısından kız ve erkek öğrenciler arasında 
anlamlı bir fark olmamasına rağmen, toplam puan ortalamalarından yola çıkarak kız öğrencilerinin takım çalışmasına daha yatkın oldukları söylenebilir.

Araştırmada ortaokul öğrencilerinin takım çalışması ve karar verme eğilimleri sınıf düzeyi açısından incelendiğinde, yedinci sınıf öğrencilerinin karar verme eğilimlerinin beşinci sinıf öğrencilerinden istatistiksel olarak anlamlı düzeyde daha olumlu olduğu belirlenmiştir. Dolayısıyla genel anlamda öğrencilerin sınıf düzeyi arttıkça karar verme eğilimlerinde de olumlu bir artış olduğu belirlenmiştir. Literatürde ortaokul öğrencilerinin karar verme eğilimlerini sınıf düzeyine göre incelemeye yönelik bir araştırma bulgusuna rastlanmamıştır. Diğer taraftan öğrencilerin sınıf düzeyine göre takım çalışması eğilimleri incelendiğinde en düşük puan ortalamasına sekizinci sınıf öğrencilerinin sahip olduğu görülmüştür. Özellikle beşinci ve altıncı sınıf öğrencilerinin takım çalışması eğilimlerinin sekizinci sınıf öğrencilerinden istatistiksel olarak anlamlı düzeyde daha olumlu olduğu belirlenmiştir. $\mathrm{Bu}$ durum öğrencilerin sınıf düzeyi arttıkça takım çalışması eğilimlerinde azalma olduğuna işaret etmektedir. İlgili literatürde ortaokul öğrencilerinin takım çalışması eğilimlerini incelemeye yönelik doğrudan bir araştırmaya rastlanmamıştır. Bu konuda Deveci (2018) ortaokul öğrencilerinin girişimcilik eğilimini incelediği araştırmasında faktörlerinden biri olarak ele aldığı takım çalışmasına ilişkin olarak, düşük sınıf düzeylerinde öğrencilerin takım çalışması eğilimlerinin daha olumlu olduğunu belirlemiştir. Deveci (2018)'in ulaştığı bu sonuçta mevcut araştırma sonucunu destekler niteliktedir. Diğer taraftan Deveci, Konuş ve Aydız (2018) araştırmalarında, 2018 yılı Fen Bilimleri Dersi Öğretim Programı kazanımlarını yaşam becerileri açısından incelemiş ve sonuçta, kazanımlarda üçüncü sınıf düzeyi dışında öğrencilerin takım çalışması yapmalarına yönelik ifadelere yer verilmediğini belirtmişlerdir. Aslında Deveci, Konuş ve Aydız (2018)'in ulaştığ 1 bu sonuçlar mevcut araştırmada ulaşılan sonucun nedenini ortaya koyma noktasında önemli görülebilir. Kazanımlarda takım çalışmasına yönelik bir ifade göremeyen öğretmenler yeterince takım çalışması yapmaya yönelik etkinliklere yer vermiyor olabilirler. Örneğin; Yücel ve Kanyılmaz (2018) yaşam becerilerine ilişkin sınıf öğretmenlerinin görüşlerini incedikleri araştırmaları sonucunda, yaşam becerilerinin kazandırılmasına yönelik olarak dokuz öğretmenden yedisinin böyle bir ders planı yapmadıklarını belirtmişlerdir. Bu anlamda Thomas (2002) okullarda birlikte çalışmanın önemine fazla dikkat edilmediğine vurgu yapmıştır. Oysaki, Krech, Crutchfield ve Ballachey (1962) grup çalışmalarındaki değişkenleri; grup büyüklüğü, grup üyelerinin becerileri, üyelerin heterojenliğinden oluşan yapısal değişkenler; görevin niteliği ve zorluk derecesinden oluşan görev değişkenleri; son olarak, fiziksel ortam ve diğer gruplarla olan ilişkileri temel alan bağlamsal değişkenler olarak ifade etmiştir (Thomas, 2002). Öyleyse öğretmenlerin bu değişkenlere dikkat etmemeleri, öğrencilerin takım çalışması eğilimlerindeki azalmanın nedenlerinden biri olarak gösterilebilir. Aslında öğretmenlerin sınıf içerisinde oluşturdukları her grup çalışmasının takım çalışması niteliği taşımadığı unutulmamalıdır. Dolayısıyla öğretmenlerin grup etkinliklerini takım çalışmasının doğasına uygun bir şekilde gerçekleştirmemesi de öğrencilerde sınıf düzeyi arttıkça takım çalışmasına yönelik olumsuz bir eğilim yaratmış olabilir. Sonuç olarak mevcut araştırma sonucunda beşinci sınıftan sekizinci sınıfa doğru öğrencilerin takım çalışması eğilimlerinde bir azalma olduğu belirlenmiştir.

Araştırmada incelenen bir diğer bağımsız değişken akademik başarı değişkeni olmuştur. Araştırmaya katılan ortaokul öğrencilerinden akademik başarı ortalaması 85 ve üzeri olan öğrencilerin akademik başarı ortalaması 0-69 ve 70-84 aralığında olan öğrencilere göre karar 
verme eğilimlerinin daha olumlu olduğu görülmüştür. Bu anlamda akademik başarısı yüksek olan öğrencilerin, akademik başarısı düşük olan öğrencilere göre tek başlarına karar verme eğiliminde oldukları söylenebilir. Diğer taraftan başarı ortalaması 85 ve üzeri olan öğrenciler ile 70-84 aralığında olan öğrencilerin, başarı ortalaması 0-69 aralığında olan öğrencilere göre takım çalışmasına daha yatkın oldukları belirlenmiştir. Bu durum akademik başarısı yüksek öğrencilerin takım çalışmasına daha yatkın olduklarını göstermektedir.

Araştırmada öğrencilerin karar verme ve takım çalışması eğilimleri arasında düşük düzeyde pozitif bir ilişki olduğu belirlenmişti. Dolayısıyla öğrencilerin takım çalışması eğilimleri arttıkça karar verme eğilimlerinin düşük düzeyde de olsa artış göstereceği söylenebilir. Bu durum takım çalışmasındaki eğilimlerin karar verme eğilimlerindeki değişimin \% 4'ünü açıklamasıyla da desteklenebilir. Bu anlamda gerek ilişki katsayısı gerekse de regresyon sonuçları dikkate alınarak bu iki değişkenin bir birlerini çok fazla etkileyen değişkenler oldukları söylenemez. Bu durum, kendi kararlarını alma ya da bireysel karar alma eğiliminde olan öğrencilerin takım çalışması içerisinde ortak bir karar üzerinde uzlaşmada zorlanabilmelerine bağlanabilir.

\section{Öneriler}

$\mathrm{Bu}$ araştırmada takım çalıması ile karar verme eğilimi arasında düşük düzeyde bir ilişki olduğu bulunmuştu. Ayrıca takım çalışması eğilimlerinin karar verme eğilimlerindeki değişimin \% 4'ünü açıkladığı belirlenmişti. Dolayısıyla takım çalışması temelli işbirlikli öğretim süreçlerinin öğrencilerin karar verme eğilimleri üzerindeki etkisi deneysel çalışmalarla test edilebilir. Diğer taraftan bu araştırmada sınıf düzeyi arttıkça öğrencilerin takım çalışması eğilimlerinde bir azalma olduğu belirlenmişti. Gelecek araştırmalarda sınıf düzeyi arttıkça takım çalışması eğilimlerindeki azalmanın nedenleri nitel araştırmalarla derinlemesine irdelenebilir. Ayrıca takım çalışması eğilimleri ile ilgili olarak farklı örneklem gruplarında yürütülecek benzer araştırmaların sonuçları mevcut araştırma sonuçları ile kıyaslanması açısından önemli olabilir. Son olarak araştırmada kız öğrencilerin karar verme eğilimlerinin erkek öğrencilerinkinden daha olumlu olduğu belirlenmişti. Erkek öğrencilerin karar verme eğilimlerindeki olumsuzluğun nedenleri yürütülecek nitel araştırmalar ile irdelenebilir. 


\section{Kaynakça}

Acock, A.C. (2005). Working with missing values. Journal of Marriage and family, 67(4), 1012-1028.

Adair, J. (2007). Decision making \& problem solving strategies. London: Kogan Page

Aksoy, G. ve Doymuş, K. (2011). Fen ve teknoloji dersinin laboratuvar öğretiminde işbirlikli öğrenmenin etkisi. Erzincan Eğitim Fakültesi Dergisi, 13(1),107-122.

Altıntaş, L. ve Alimoğlu, M.K. (2016). Takım çalışmasına dayalı öğrenme. Turkiye Klinikleri J Med Educ-Special Topics, 1(1), 33-40.

Altun, S. (2017). The effect of cooperative learning on students' achievement and views on the science and technology course. International Electronic Journal of Elementary Education, 7(3), 451-468.

Arslan, S., Taşkın, D. ve Kirman-Bilgin, A. (2015). Adidaktik öğrenme ortamlarında bireysel ve grup çalışması uygulamalarının öğrenci başarısına etkisi. Turkish Journal of Computer and Mathematics Education, 6(1), 47-67.

Ayanoğlu, Ç. ve Hamedoğlu, M.A. (2013). Team perception of the teachers in the primary schools. Sakarya University Journal of Education, 3(1), 54-62.

Bacanlı, F. ve Sürücü, M. (2006). ilköğretim 8. sınıf öğrencilerinin sınav kaygıları ve karar verme stilleri arasındaki ilişkilerin incelenmesi. Kuram ve Uygulamada Egitim Yönetimi Dergisi, 12(1), 7-35.

Bilgin, İ., ve Gelici, Ö. (2011). İşbirlikli öğrenme tekniklerinin tanıtımı ve öğrenci görüşlerinin incelenmesi. Adlyaman Üniversitesi Ĕgitim Bilimleri Dergisi, 1(1), 40-70.

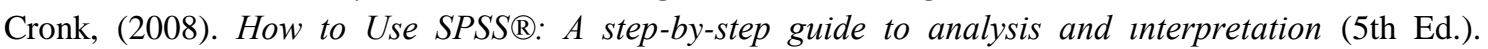
Californi: Pyrczak Publishing.

Çakmakçı, E. (2009). Karar verme becerilerinin kazandırlmasında drama dersinin ilköğretim 4. slnıf ögrencileri üzerindeki etkilerinin incelenmesi (yayınlanmamış yüksek lisans tezi). Sosyal Bilimler Enstitüsü, Eskişehir Osmangazi Üniversitesi. Eskişehir.

Çüm, S. ve Gelbal, S. (2015). Kayıp veriler yerine yaklaşık değer atamada kullanılan Farklı yöntemlerin model veri uyumu üzerindeki etkisi. Mehmet Akif Ersoy Üniversitesi Eğitim Fakültesi Dergisi, 1(35), 87-111.

Department of Education (2003). enGauge ${ }^{\circledR} 21$ st century skills: Literacy in the digital age. Los Angeles: North Central Regional Educational Laboratory and the Metiri Group. 08.02.2019 tarihinde https://pict.sdsu.edu/engauge21st.pdf den alınmıştır.

Deveci, İ. (2018). Ortaokul öğrencilerinin fen tabanlı girişimcilik eğilimlerinin incelenmesi. Fen, Matematik, Girişimcilik ve Teknoloji Eğitimi Dergisi, 1(1), 19-47.

Deveci, İ., Konuş, F. Z., \& Aydız, M. (2018). Yılı fen bilimleri dersi öğretim programı kazanımlarının yaşam becerileri açısından incelenmesi. Çukurova Üniversitesi Eğitim Fakültesi Dergisi, 47(2), 765-797.

Ergün, E. ve Eyisoy, M.E. (2018). Takım çalışması özelliklerinin takım performansına etkisi üzerine bir araştırma. Business \& Management Studies: An International Journal, 6(4), 1455-1475.

Ersoy, E. ve Deniz, M.E. (2016). Üstün yetenekli çocukların öfkeyle başa çıkma ve karar verme becerilerinin bazı değişkenler açısından incelenmesi. İlköğretim Online, 15(3), 1017-1030.

Galton, M., \& Williamson, J. (1992). Group work in the primary classroom. USA and Canada: Routledge, Chapman and Hall, Inc.

George, D., \& Mallery, P. (2016). IBM SPSS statistics 23 step by step: A simple guide and reference (14th ed.). New York: Routledge.

Guitiérrez, D., \& García-López, L. (2012). Assessment of primary school students' decision-making related to tactical contexts. Journal of New Approaches in Educational Research, 1(1), 7-12.

Gülbahçe, A. ve Kartol, A. (2014). İlköğretim sekizinci sınıf öğrencilerinin karar verme stratejilerinin bazı değişkenler açısından incelenmesi. Bayburt Eğitim Fakültesi Dergisi, 9(2), 132-143.

Gülen, S. ve Yaman, S. (2018). Altıncı sınıf öğrencilerinin FeTeMM tabanlı ATBÖ yaklaşımı etkinlikleri hakkındaki görüşleri. OPUS Uluslararası Toplum Araştırmaları Dergisi, 8(15), 1293-1322. 
Güneş, G. ve Asan, A. (2005). Oluşturmacı yaklaşıma göre tasarlanan öğrenme ortamının matematik başarısına etkisi. Gazi Üniversitesi Gazi Eğitim Fakültesi Dergisi, 25(1), 105-121.

Hobbs, T., \& Westling, D. (1998). Promoting successful inclusion through collaborative problem solving. Teaching Exceptional Children, 31, 12-19.

Karakaş, G.E. (1999). İlköğretim 4. ve 5. sinıf ögrencilerinin günlük yaşamdaki problemlerini çözmeye ilişkin karar verme becerilerini ölçmeye yönelik bir ölçek geliştirme çalışması (yayınlanmamış yüksek lisans tezi). Sosyal bilimler enstitüsü, Çukurova Üniversitesi, Adana.

Kocabaş, İ. ve Gökbaş, M. (2003). Eğitimde Takım Çalışması. Eğitim ve Bilim, 28(130), 8-15.

Köseoğlu, E. (2014). İlkokul 4. sinıflarda drama etkinlikleriyle işlenen derslerin öğrencilerin problem çözme ve karar verme becerileri üzerindeki etkilerinin incelenmesi (yayınlanmamış yüksek lisans tezi), Eğitim Bilimleri Enstitüsü, Atatürk Üniversitesi, Erzurum.

Krech, D., Crutchfield, R.S., \& Ballachey, E.L. (1962). Individual in Society: A Textbook of Social Psychology. New York: McGraw-Hill.

Lawrence-Brown, D., \& Muschaweck, K. S. (2004). Getting started with collaborative teamwork for inclusion. Catholic Education: A journal of inquiry and practice, 8(2), 146-161.

Lodico, M.G., Spaulding, D.T., \& Voegtle, K.H. (2006). Methods in educational research: From theory to practice. San Francisco: John Wiley \& Sons.

Mackall, D.D. (2004). Careers skills library: teamwork skills (2nd Ed.). New York: Ferguson Publishing.

MEB, (2013). İlkögrretim kurumları (ilkokullar ve ortaokullar) fen bilimleri dersi ögrretim programı. Ankara: Talim ve Terbiye Kurulu Başkanlığı.

MEB, (2017). Fen bilimleri dersi ögretim programı (ilkokul ve ortaokul 3, 4, 5, 6, 7, 8. sinıflar). Ankara: Temel Eğitim Genel Müdürlügü.

MEB, (2018a). Fen bilimleri dersi ögretim programı (ilkokul ve ortaokul 3, 4, 5, 6, 7, 8. sinıflar). Ankara: Temel Eğitim Genel Müdürlüğü.

MEB, (2018b). Türkçe dersi ögretim programı (illkokul ve Ortaokul 1, 2, 3, 4, 5, 6, 7 ve 8. Sinfflar). Ankara: Temel Eğitim Genel Müdürlüğü.

MEB, (2018c). Beden eğitimi ve spor dersi öğretim programı (Ortaokul 5, 6, 7 ve 8. Sinıflar). Ankara: Temel Eğitim Genel Müdürlüğü.

National Research Council (2012). Education for life and work: Developing transferable knowledge and skills in the 21st century. Committee on Defining Deeper Learning and 21st Century Skills, J.W. Pellegrino and M.L. Hilton, Editors. Board on Testing and Assessment and Board on Science Education, Division of Behavioral and Social Sciences and Education. Washington, DC: The National Academies Press.

Ocak, G. ve Yurtseven, R. (2016). Ortaokul öğrencilerinin sınav kaygıları ile karar verme stilleri arasındaki ilişkinin incelenmesi. Ekev Akademi Dergisi, 20(66), 317-332.

Page, M.C., Braver, S.L., \& MacKinnon, D.P. (2003). Levine's guide to SPSS for analysis of variance (2nd Ed.). London: Lawrence Erlbaum Associates.

Pallant, J. (2007). SPSS survival manual: A step by step guide to data analysis using SPSS for Windows. 3th edition, New York: McGraw-Hill Education.

Pekdoğan, S. ve Ulutaş, İ. (2018). Karar verme becerileri eğitim programının okul öncesi dönem çocuklarının karar verme becerileri üzerindeki etkisi. Inonu University Journal of the Faculty of Education (INUJFE), 19(1), 230-244.

Rojas, M.D., Alis, J.E., \& Londono, L.M. (2013). Teamwork for decision-making through games: The Case of On-Line "Manage-Art". Developments in Business Simulation and Experiential Learning, 40, 244-250.

Slavin, R., Hurley, E.A., \& Chamberlain, A. (2003). Cooperative learning and achievement: Theory and research. In W.M. Reynolds \& G.E. Miller (Eds.), Handbook of psychology: Educational psychology (pp.177-198). New York: Wiley 
Stacey, M. (2009). Teamwork and collaboration in early years settings. Learning Matters. Exeter: Learning Matters Ltd.

Tabachnick, B.G., \& Fidell, L.S. (2007). Using multivariate statistics (5th ed.). Boston: Pearson Education.

Talaslığlu, S.S. ve Şahin, F. (2018). Ortaokul 7. Sınıf öğrencilerinin grafik okuryazarlığı etkinlikleri ile karar verme becerileri ve kavram öğrenmeleri arasındaki ilişkinin incelenmesi. Journal of Human Sciences, 15(1), 62-76.

Tayran, N. ve Ulupınar, S. (2011). Bir ölçek geliştirme çalışması: İzolasyon önlemlerine uyum ölçeğinin geçerlik ve güvenirliği. Florence Nightingale Hemşirelik Dergisi, 19(2), 89-98

Tekin, S. ve Ulaş, A. (2016). İlkokul 4. sınıf öğrencilerinin karar verme becerilerine ilişkin bir araştırma. Qualitative Studies, 11(3), 27-38.

Tetik, A.T. (2013). Sosyal bilgiler dersinde kullanılan probleme dayalı ögrrenme yönteminin ögrencilerin karar verme becerisine etkisi (yayınlanmamış yüksek lisans tezi). Eğitim Bilimleri Enstitüsü, Mehmet Akif Ersoy Üniversitesi, Burdur.

Thomas, G. (2002). Effective classroom teamwork: Support or intrusion? London: Taylor \& Francis.

Tofur, S. ve Balıkçı, A. (2018). Okul yöneticileri ve öğretmenlere göre okul iklimini etkileyen faktörlerin incelenmesi: ortaokul örneği. Electronic Turkish Studies, 13(11), 1279-1295.

Viscuso, F. (2015). Step up your teamwork. Oklahoma: PennWell Corporation

Yılmaz, T.K., Baydaş, Ö. ve Kokoç, M. (2017). Grup çalışması ortamlarına karşı öğrenci tutumları ölçeğinin (GÇOÖT) Türkçeye uyarlanması. Ilköğretim Online, 16(3), 1049-1057.

Yücel, E.Ö. ve Kanyılmaz, B.M. (2018). Fen bilimleri dersi öğretim programında yer alan yaşam becerilerinin ilkokul öğrencilerine kazandırılmasına yönelik öğretmen görüşlerinin değerlendirilmesi. Eğitimde Nitel Araştırmalar Dergisi, 6(3), 10-33. 


\section{Extended Abstract}

\section{Introduction}

It is emphasized that the decision-making and teamwork inclinations on the part of middle school students should be developed at both national and international level. Decision-making is about deciding which action to take and often requires a choice between options (Adair, 2007). On the other hand, according to Mackall (2004), teamwork is seen as the process involving a group of people working together and bringing together their resources and skills in order to achieve a common goal. On the other hand, according to Viscuso (2015), teamwork is seen as the ability of working in a group in order to achieve a common vision. In the related literature, no studies have aimed to investigate the middle school students' decision making and teamwork inclinations in terms of gender, grade level and academic success. It was also determined that there is no any study aimed to investigate the relationship between the middle school students' teamwork and decision making inclinations. It is thought that this gap in the literature will be filled by this research. One of the objectives of teamwork is for students to arrive at a common decision (Lawrence-Brown \& Muschaweck, 2004). Thus, in cooperative processes, students are involved in the decision-making process in order to solve problems (Hobbs \& Westling, 1998). However, Stacey (2009) is noteworthy in pointing out that the decision-making process will be inefficient in any group in which the spirit of teamwork is not included. In this sense, it can also be said that the relationship between the middle school students' teamwork inclinations and decision making inclinations should be examined. The purpose of this research is to examine the students' teamwork and decision making inclinations in terms of gender, grade level and academic success, as well as to determine the relationship between teamwork and decision making inclinations. In line with this purpose, the sub-problems of the research are as follows:

- Is there a statistically significant difference in terms of gender, grade level, and academic success with regard to students' teamwork inclinations?

- Is there a statistically significant difference in terms of gender, grade level, and academic success with regard to students' decision making inclinations?

- Is there a relationship between the students' teamwork inclinations and the students' decision making inclinations?

- Do the students' teamwork inclinations predict their decision-making inclinations statistically?

\section{Method}

In this study, non-experimental quantitative approaches were preferred. These consisted of a causal-comparative research design and a correlational research design. This study used a causal-comparative research design because the aim is to examine whether or not there are statistically significant differences in terms of gender, grade level and academic success with regard to the decision-making and teamwork tendencies. Moreover, correlational research design was used because the aim was also to examine the relationship between the students' teamwork inclinations and their decision making inclinations. The research sample is composed of 522 th-8th grade middle school students. In the study, a convenience sampling method was used. The "Student Attitudes Towards Group Environments Scale" and the "Decision Making 
Scale" were used as data collection tools. Three-way MANCOVA, ANCOVA, simple correlation analysis and simple linear regression analysis were used to analyze the data. Before the analysis, assumptions such as normal distribution, multicollinearity and singularity, linearity, homogeneity of variances, and sample size were met.

\section{Results and Discussion}

When the students' decision-making inclinations were examined, it was determined that female students were more positive than male, seventh grade students were more positive than fifth grade students, and students with higher GPAs were more positive than those with lower GPAs. When the students' teamwork inclinations are examined, it was determined that there is no significant difference in terms of gender, fifth and sixth grade students were more positive than eighth grade students, and students with a high average GPA were more positive than those with lower GPAs. On the other hand, there was a low positive relationship between students' teamwork and their decision making inclinations. In addition, it was determined that the students' teamwork inclinations significantly predicted their decision-making inclinations by $4 \%$. As a result, it was determined that there were decreased teamwork inclinations on the part of the students as the grade level increased. In future studies, as the grade level increases, a decrease in the tendency with regard to teamwork inclinations can be explored through the use of qualitative research. In addition, the female students' decision-making inclinations were found to be more favorable than those of male students. The negativity of male students' in terms of decision making inclinations can be examined through the use of qualitative research. 